\title{
Adverbial Subordinator Prefixes ${ }^{1}$
}

Matthew S. Dryer

University at Buffalo

Dryer (2013a) describes a number of ways in which languages mark adverbial clauses for their semantic relation to the main clause. One way is to use separate words, either at the beginning of the clause or at the end of the clause (or, more rarely, internal to the clause). Another type uses suffixes on verbs. The remaining type contains languages with more than one means of marking adverbial clauses, none of which is dominant. ${ }^{2}$

What is absent from this list of types are languages which employ prefixes on verbs as adverbial subordinators: Dryer (2013a) lists 64 languages (out of a sample of 659 languages) that use suffixes to mark adverbial clauses but none that use prefixes. Does this mean that prefixal adverbial subordinators are unattested? The goal of this paper is to show that that is not the case. I report here on five languages that employ prefixal adverbial subordinators, although in four of these languages, there is another type of adverbial subordinator (like separate words or suffixes), with neither type of adverbial subordinator dominant, so these would be classified in the typology of Dryer (2013a) as languages with more than one means of marking adverbial clauses, none of which is dominant.

Following Dryer (2013a), I define adverbial subordinators as morphemes that occur in adverbial subordinate clauses and that code the particular semantic relation between that clause and the matrix clause. When these morphemes are separate words, they are traditionally called subordinate conjunctions, like the English words because, although, and while (though the traditional expression 'subordinate conjunction' also applied to words marking other types of subordinate clauses, like complementizers). Following Dryer (2013a), morphemes that mark an adverbial clause as subordinate without coding a particular relation between the clause and the matrix clause are not considered to be adverbial subordinators. I also exclude morphemes that could be construed as part of the tense-aspect system by indicating whether the event in the subordinate clause and the event in the main clause are sequential or simultaneous.

I report here on one language in which prefixal adverbial subordinators are the dominant mechanism, namely Gumuz. The other four languages are Muna, Tashlhiyt (aka Shilha), Mitla Zapotec, and Maricopa. Three of these languages also employ clause-initial adverbial subordinator words in addition to the subordinator prefixes, while the fourth employs subordinator suffixes in addition to prefixes. The purpose of this paper is to document these five instances of languages that employ prefixes on verbs as adverbial subordinators. I also discuss briefly languages with clause-initial subordinator clitics that procliticize onto whatever is the first word in the clause. ${ }^{3}$

\footnotetext{
${ }^{1}$ I am indebted to Lea Brown for comments on an earlier version of this paper. I also acknowledge funding from The Social Sciences and Humanities Research Council of Canada, the National Science Foundation (in the United States), the Max Planck Institute for Evolutionary Anthropology (in Leipzig, Germany) and the Humboldt Foundation (in Germany).

${ }^{2}$ See Dryer (2013b) for an explanation of the criteria for treating one mechanism as dominant.

${ }^{3}$ Merrifield (1968) describes two morphemes in Palantla Chinantec that he represents as part of the word that follows. In all of the examples that I have found, these morphemes are attached to verbs (the language is verb-initial), suggesting that they might be prefixal adverbial subordinators. However in a later dictionary (Merrifield and Anderson 1999), these two morphemes are represented as separate words.
} 


\section{Gumuz}

The one language that I am aware of that employs subordinator prefixes as the primary mechanism for marking adverbial clauses is Gumuz, a language spoken in Ethiopia that is sometimes classified as a language isolate (or as one of two languages in a small Gumuz family) and sometimes classified as Nilo-Saharan. Ahland (2012) describes two distinct dialects, Northern Gumuz and Southern Gumuz and it is the northern dialect that is relevant here. ${ }^{4}$ This dialect has a prefix nágw$\sim$ go- that is used for when-clauses, as in (1), or because-clauses, as in (2). ${ }^{5}$

\section{(1) Ká łá nágw-a-s paatúú-baga ná=fá á-ka-zig=angó porcupine TEMP-3SG.TRANS-eat pumpkin-person LOC=tree 3SG.INTRANS-COM-sleep=NEG 'When a porcupine eats a person's pumpkin, he doesn't sleep with it in a tree.'}

Ahland (2012: 433)

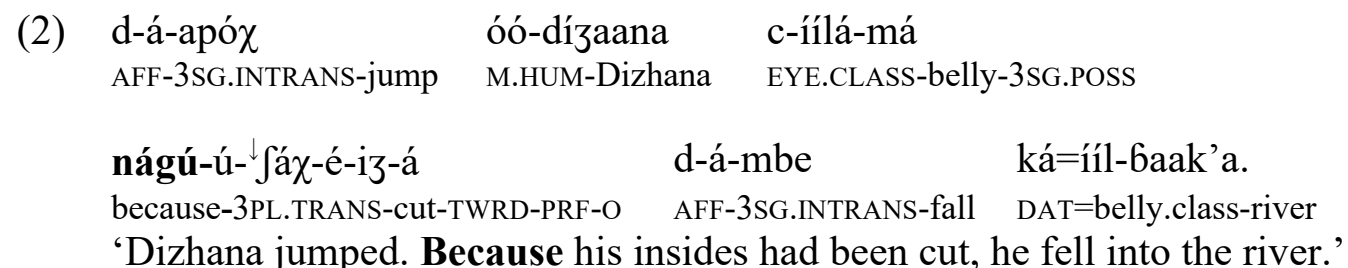

(Ahland 2012: 442)

\section{Muna}

Muna (van den Berg 1989/2013) is an Austronesian language spoken on Sulawesi in Indonesia. This language has three prefixal adverbial subordinators, sa- 'when', paka- 'when first' and ta'until', illustrated in (3) to (5) respectively.
sa-no-wora
ghule, ne-kansuru
no-logha-e.
when-3SG.REAL-see
snake 3SG.REAL-at.once 3SG.REAL-stab-him

'As soon as he saw the snake, he stabbed him right away.' (van den Berg 1989: 271)

(4)

$\begin{array}{lll}\text { paka-gaa-ndo } & \text { sadhia } & \text { do-pogira. } \\ \text { when.first-marry-their } & \text { always } & \text { 3PL.REAL-fight }\end{array}$

'When they were just married, they were always fighting.' (van den Berg 1989: 250)

\footnotetext{
${ }^{4}$ In the southern dialect, there is also a separate word for 'because' that precedes the verb and a morpheme that is sometimes prefixed to the verb and sometimes a separate word preceding the verb, so that this dialect cannot be classified as using prefixes as the primary means of marking adverbial clauses.

${ }^{5}$ This paper assumes that the representations in grammatical sources of morphemes as affixes as opposed to separate words are accurate. This assumption is probably not always true (Haspelmath 2011). However, the Gumuz prefix described here exhibits phonologically conditioned allomorphy, so in this case, its treatment as an affix by Ahland (2012) is well-motivated. It is also possible that there are languages in which morphemes are represented as separate words where the phonology might provide reason to say that they are actually prefixes.
} 

(5)
$\begin{array}{lllll}\text { ne-late } & \text { bhe } & \text { awa-no } & \text { ini-a } & \text { ta-no-bhala-hi-mo. } \\ \text { 3SG.REAL-live } & \text { with } & \text { grandparent-his } & \text { this-CL } & \text { until-3sR-big-HI-PF }\end{array}$

'Until he was grown up he lived with his grandmother.' (van den Berg 1989: 250)

But the language also has adverbial subordinators which are separate words that appear at the beginning of the clause, including mahingga 'although', illustrated in (6), and rampahano 'because', illustrated in (7). ${ }^{6}$

(6) mahingga de-tula-tula-ane miina na-[m]arasaea.

although 3PL:REAL-REDUP-tell-him not 3SG.IRREAL-believe

'Although they told him, he did not believe (it).' (van den Berg 1989: 261)

$\begin{array}{llllll}\text { (7) miina } & \text { na-k[um]ala } & \text { we } & \text { sikola } & \text { rampahano } & \text { no-saki. } \\ \text { not } & \text { 3sG.IRREAL-go } & \text { LOC } & \text { school because } & \text { 3sG.REAL-sick }\end{array}$

'He has not gone to school because he is ill.' (van den Berg 1989: 262)

The subordinator rampahano 'because' can also follow the clause, as in (8).

$\begin{array}{llllll}\text { (8) miina } & \text { na-[m]oni telo lambu, no-tehi } & \text { rampahano. } \\ \text { not } & \text { 3sI-go.up } & \text { in } & \text { house } & \text { 3sR-afraid } & \text { because }\end{array}$

'He did not enter the house because he was afraid' (van den Berg 1989: 262)

Muna also has a word kaawu 'after' which occurs inside the clause, following the verb and preceding the subject, as in (9), where it follows the verb nomate 'die' and precedes the subject ghule 'snake'.
no-mate
kaawu ghule
amaitu,
andoa do-si-suli-ha-mo.
3SG REAL-die
after
snake
that they
3PL.REAL-SI-return-HA-PERF

'When the snake was dead, they went home together' (van den Berg 1989: 250)

In other words, although Muna has prefixal adverbial subordinators, it also has adverbial subordinator words occurring in a variety of positions and hence is classified as lacking a dominant type for the purposes of the typology in Dryer (2013a).

\section{Tashlhiyt}

Tashlhiyt, also known as Shilha, is a Berber language spoken in Morocco. Applegate (1958: 27) describes some prefixes that count as adverbial subordinators, including ones meaning 'when', 'if', and 'as soon as'. The first two of these are illustrated in (10) and (11) respectively. ${ }^{7}$

\footnotetext{
${ }^{6}$ It is not entirely clear what van den Berg's criteria are for treating sa-, paka- and ta- as affixes but mahingga as a separate word, but it is implicit that it is partly based on stress and partly based on the fact that the former immediately precede subject prefixes obligatorily, while the latter can apparently be separated from the verb by a subject noun phrase (though I find no examples illustrating this).

${ }^{7}$ Applegate's criteria for treating these two morphemes as affixes rather than as separate words is that they occur in the same position as other prefixes which cause pronominal object affixes that otherwise occur as suffixes to occur as prefixes. Part of the motivation for treating these other affixes as affixes rather than as separate words is that some of them are non-syllabic.
} 


$\begin{array}{lllll}\text { lig-i-iuuri } & \text { žha } & \text { s-tigmi } & \text { i-dub } & \text { zift. } \\ \text { when-3sG-return } & \text { (name) } & \text { to-house } & \text { 3sG-melt } & \text { tar }\end{array}$

'When Zha returned to the house, he melted tar.' (Applegate 1958: 39)

(11) ig-a-saual guan guad ar-i-t-xam: bzaf: if-PROG-talk that this PROG-3SG-HABIT-think much 'If that one talks, this one thinks a lot.' (Applegate 1958: 42)

His examples also include two instances of initial subordinators that are separate words, one meaning 'until' and a second meaning 'because', illustrated in (12) and (13) respectively.

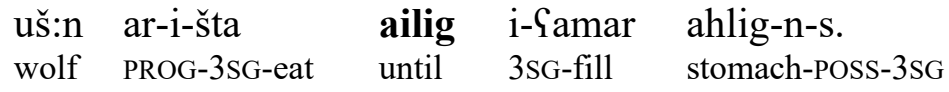

'The wolf ate until he filled his stomach.' (Applegate 1958: 38)

(13) i-ksim aškun i-ḥma lḥal.

3SG-enter because 3SG-hot weather

'He went in because the weather was hot.' (Applegate 1958: 36)

Although Tashlhiyt has prefixal adverbial subordinators, it also has separate clause-initial words serving that function.

\section{Mitla Zapotec}

Mitla Zapotec (Briggs 1961) is an Otomanguean language spoken in southern Mexico. It has prefixes for 'because' and 'when' illustrated in (14) and (15) respectively. ${ }^{8}$

(14) zak-wíh-ni

because-go-3SG

'because he went' (Briggs 1961: 60)

(15) tši-bidzuuhn-ni

when-arrive-3SG

'when he arrived' (Briggs 1961: 59)

It also has adverbial subordinators which are separate words that occur at the beginning of clauses, as in (16) to (18).

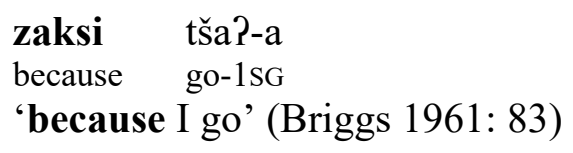

${ }^{8}$ At least part of Briggs' motivation for treating these morphemes as affixes rather than separate words is that they apparently trigger tonal changes in the stems they attach to (p. 10). 
(17)

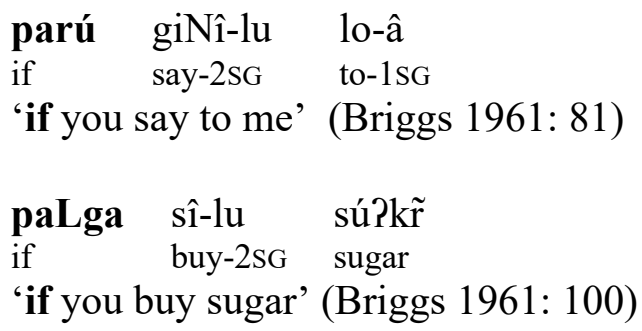

As with Muna and Tashlhiyt, Mitla Zapotec seems best classified as a language that has adverbial subordinators which are prefixes or separate words, with neither dominant.

\section{Maricopa}

Maricopa (Gordon 1986) is a language in the Yuman family, spoken in Arizona in the southwestern United States. It has a prefix nya- meaning 'when' illustrated in (19) and a suffix -haayly with similar meaning illustrated in (20). Gordon analyses the suffix -haayly as a combination of two morphemes -haay 'yet' and -ly 'in, into'.

(19) Pan nya-m-chew-m '-maa-num.

bread when-2-make-DIFF.SUBJ 1-eat-INCOMPL

'When you bake the bread, I'll eat it.' (Gordon 1986: 266)

$$
\begin{array}{lll}
\text { '-ashvar-haay-ly } & \text { '-nchen-sh } & \text { iima-k. } \\
\text { 1-sing-yet-in } & \text { 1-old.sibling-SUBJ } & \text { dance-REAL }
\end{array}
$$

'When I sang, my brother started to dance' (Gordon 1986: 270)

Gordon provides no evidence that one of these is dominant.

\section{Clause-initial adverbial subordinator clitics}

In addition to these languages with prefixal adverbial subordinators, there are also languages which have adverbial subordinators which are proclitics which attach to the first word in the clause, regardless of its category. For example in (21) from Musqueam (Suttles 2004), a Salishan language spoken in western Canada, the subordinator $2 \partial t=$ 'whenever' attaches to an auxiliary particle, while in (22) it attaches to the verb.

$$
\begin{array}{llll}
\text { ni } & \text { Pəlyə-mət-əs } & \text { Pəl=ni?-əs } & \text { Pítət. } \\
\text { AUX } & \text { have.vision-CON-3TRANS } & \text { whenever=AUX-3suB } & \text { sleep }
\end{array}
$$

'He dreams about it whenever he goes to sleep.' (Suttles 2004: 94)

(22) stə?é $\quad \check{x} x^{w} \quad$ Pəl=q"al-st-ámə-?è·n.

be.like you whenever=speak-COMIT-2SG.OBJ-1SG.SUBJ

'You comply whenever I speak to you.' (Suttles 2004: 94)

\footnotetext{
${ }^{9}$ The basis for Gordon treating nya- as a prefix rather than as a separate word is not clear.
} 
Similarly in (23) from Chalcatongo Mixtec (Macaulay 1996), an Otomanguean language spoken in Mexico, the subordinator $s a ́=$ 'when' attaches on to the subject noun phrase María, while in (24), it attaches to the verb.

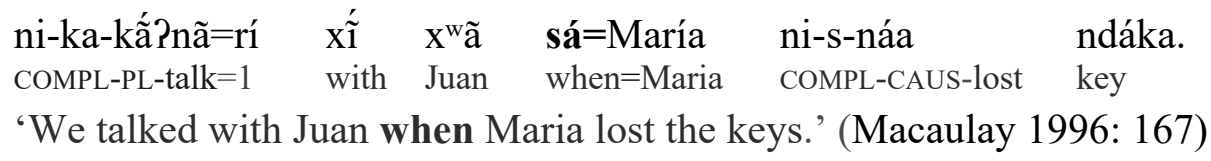

$$
\begin{array}{llll}
\text { ni-kéndá }=\text { rí } & \begin{array}{l}
\mathbf{s a}=\text { nì-s-ndiPi=rí } \\
\text { when=COMPL-CAUS-end=1 }
\end{array} & \begin{array}{l}
\text { ni-žéé=rí } \\
\text { cOMPL-eat }=1
\end{array} & \begin{array}{l}
\text { staà. } \\
\text { tortilla }
\end{array}
\end{array}
$$

'I left when I finished eating.' (Macaulay 1996: 167)

And in (25) from Lampung (Walker 1976), an Austronesian language spoken in Indonesia, the clitic $k i=$ 'if' attaches to the subject pronoun tian '3PL'.

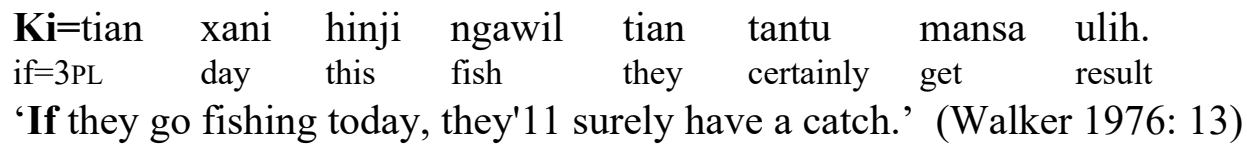

Other languages in my database with clause-initial subordinator proclitics are Sahidic Coptic (Lambdin 1983, Plumley 1948), Assyrian Neo-Aramaic (Khan 2008), and Fijian (Dixon 1988).

\section{Discussion}

Although there exist these instances of prefixal adverbial subordinators, it is clear that they are relatively rare. And there is only one attested language in which they are the dominant form of adverbial subordinators (in contrast to the 64 languages in Dryer (2013a) in which the dominant form of adverbial subordinators is suffixes on verbs). A natural question is why prefixal adverbial subordinators are so rare compared to suffixal adverbial subordinators.

One obvious factor is the suffixing preference (Greenberg 1957; Cutler, Hawkins and Gilligan 1985; Hawkins and Cutler 1988; Hawkins and Gilligan 1988; Hall 1988, 1992; Bybee et al 1990; Himmelmann 2014; Asao 2015). ${ }^{10}$ However, the rarity of adverbial subordinator prefixes implies that the suffixing preference is stronger for adverbial subordinator affixes than for most types of affixes. There are two considerations that are worth mentioning that may play a role in explaining this.

The first consideration is that the strong suffixing preference for adverbial subordinators may be related to the fact that there is also a particularly strong suffixing preference for case affixes: Dryer (2013c) lists 432 languages with case suffixes but only 38 with case prefixes. Adverbial subordinators resemble case affixes and adpositions semantically in that both are typically signaling the semantic or grammatical relationship of something to a verb, where that something is a clause in the case of adverbial subordinators and a noun phrase in the case of adpositions and case affixes. It is not uncommon crosslinguistically for morphemes to function both as adpositions and as adverbial subordinators, like after in English (after the game, after he left) and even when this is not the case, there are often pairs of adverbial subordinators and adpositions that correspond

\footnotetext{
${ }^{10}$ Because the issues surrounding explaining the suffixing preference are so complex, discussion of them is beyond the scope of this paper.
} 
to each other semantically, like although and despite (or while and during) in English. There are also languages in which there are affixes that function either as adverbial subordinators or as case affixes. For example, the locative case suffix - $d a$ in Tyvan (Anderson and Harrison 1999), a Turkic language spoken in Siberia, functions either as an adverbial subordinator, as in (26), or as a case suffix on nouns, as in (27).
Iyi xon-gan-da
Badiy
aki-m-dan
aytir-di-m.
two spend.night-PAST-LOC
Badiy
older.brother-1SG-ABL
ask-PAST-1SG
'When two days had passed, I asked my brother Badiy.'

(Anderson and Harrison 1999: 82)

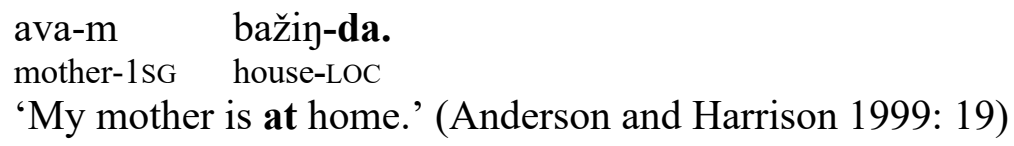

While it is plausible that the rarity of prefixal adverbial subordinators is related to the relative rarity of case prefixes, it is not clear why the suffixing preference is particularly strong for case prefixes, so that the similarity of adverbial subordinator prefixes to case prefixes does not really explain why adverbial subordinator prefixes are as rare as they are.

A second consideration is that if affixal adverbial subordinators typically arise historically from adverbial subordinators that are separate words, we would expect that suffixes would usually arise in verb-final languages and prefixes in verb-initial languages, since it is in those languages that adverbial subordinators would normally be immediately adjacent to the verb. This is only partly borne out in that only two of the five languages discussed in this paper with prefixal adverbial subordinators, Tashlhiyt and Mitla Zapotec, are verb-initial. Muna is SVO in transitive clauses, but VS in intransitive clauses, while Maricopa is SOV and Gumuz is SVO/SOV. If there is a universal tendency for transitive subjects not to be full noun phrases (Du Bois 1987), then the verb would typically be at the beginning of clauses in Muna, since subject pronouns are generally absent in Muna.

The rarity of prefixal adverbial subordinators might thus be due in part to the fact that verbinitial languages are considerably less common than verb-final languages: in the sample in Dryer (2013d), SOV languages outnumber verb-initial languages by 565 to 120 . But an additional factor is that while rigidly verb-final languages, where the verb is always or normally at the end of the clause, are common, rigidly verb-initial languages are not. This is implied by Universal 6 of Greenberg (1963) ("All languages with dominant VSO order have SVO as an alternative or as the only alternative basic order.") A further factor is that there is a general preference for clause-initial adverbial subordinator words over clause-final ones: in Dryer (2013a), clause-initial adverbial subordinator words outnumber clause-final adverbial words by 398 to 98 , and while clause-initial subordinators are common in OV languages (my data includes $73 \mathrm{OV}$ languages where the dominant type of adverbial subordinator is clause-initial words), clause-final subordinators are rare in VO languages (my data includes only $4 \mathrm{VO}$ languages where the dominant type of adverbial subordinator is clause-final). This means that languages in which adverbial subordinator words that always occur immediately following the verb will be much more common than languages where these always occur immediately before the verb.

Note that languages with clause-initial adverbial subordinator clitics are almost as common as languages with clause-final adverbial subordinator clitics (six of the former, nine of the latter). While my data show that there is also a crosslinguistic preference for enclitics over proclitics, this 
preference is especially weak for adverbial subordinator clitics, the opposite of what we find with adverbial subordinator affixes. The fact that it is far more common in language for clauses with final subordinators to immediately follow verbs than it is for clauses with initial subordinators to immediately precede verbs would explain both the rarity of adverbial subordinator prefixes and the contrasting relatively higher frequency of adverbial subordinator proclitics.

\section{References}

Ahland, Colleen Anne. 2012. A grammar of Northern and Southern Gumuz. University of Oregon doctoral dissertation.

Anderson, Gregory D. \& David K. Harrison. 1999. Tyvan. München: Lincom.

Applegate, Joseph R. 1958. An outline of the structure of Shilha. Program in Oriental Languages Publications Series B. Washington, D.C: American Council of Learned Societies.

Asao, Yoshihiko. 2015. Left-right asymmetries in words: a processing-based account. University at Buffalo dissertation.

Briggs, Elinor. 1961. Mitla Zapotec grammar. Mexico City: Instituto Lingüístico de Verano and Centro de Investigaciones Antropológicas de México.

Bybee, Joan, Pagliuca, William, and Perkins, Revere D. 1990. On the asymmetries in the affixation of grammatical material. In Studies in Diachronic Typology for Joseph H. Greenberg, ed. by William Croft, Suzanne Kemmer and Keith Denning, 1-42. John Benjamins.

Cutler, Anne, John A. Hawkins and Gary Gilligan. 1985. The suffixing preference: a processing explanation. Linguistics 23: 723-758.

Dixon, R. M. W. 1988. A grammar of Boumaa Fijian. Chicago: University of Chicago Press.

Dryer, Matthew S. 2013a. Order of adverbial subordinator and clause. In Dryer and Haspelmath (2013). (Available online at http://wals.info/chapter/94, Accessed on 2016-11-23.)

Dryer, Matthew S. 2013b. Determining dominant order. In Dryer and Haspelmath (2013). (Available online at http://wals.info/chapter/s6, Accessed on 2016-11-23.)

Dryer, Matthew S. 2013c. Position of case affixes. In Dryer and Haspelmath (2013). (Available online at http://wals.info/chapter/51, Accessed on 2016-11-23.)

Dryer, Matthew S. 2013d. Order of subject, object, and verb. In Dryer and Haspelmath (eds.) (2013). (Available online at http://wals.info/chapter/81, Accessed on 2016-11-23.)

Dryer, Matthew S. and Martin Haspelmath (eds.). 2013. The World Atlas of Language Structures Online. Munich: Max Planck Digital Library.

Du Bois, John W. 1987. The discourse basis of ergativity. Language 63: 805-855 .

Gordon, Lynn. 1986. Maricopa morphology and syntax. Berkeley, California: University of California Press.

Greenberg, Joseph. 1957. Essays in Linguistics. Wenner-Gren Foundation.

Greenberg, Joseph H. 1963. Some universals of grammar with particular reference to the order of meaningful elements. In Universals of language, ed. by Greenberg, Joseph, 73-113. Cambridge, Mass: MIT Press.

Hall, Christopher J. 1988. Integrating diachronic and processing principles in explaining the suffixing preference. In Hawkins (1988), 321- 49.

Hall, Christopher J. 1992. Morphology and mind: A unified approach to explanation in linguistics. London: Routledge.

Haspelmath, M. 2011. The indeterminacy of word segmentation and the nature of morphology and syntax. Folia Linguistica 45: 31-80. 
Hawkins, John A. 1988. Explaining Language Universals. Oxford: Oxford University Press.

Hawkins, John A., and Cutler, Anne. 1988. Psycholinguistic factors in morphological asymmetry. In Hawkins (1988), 280-317.

Hawkins, John A. and Gary Gilligan. 1988. Prefixing and suffixing universals in relation to basic word order. Lingua 74: 219-259.

Himmelmann, Nikolaus P. 2014. Asymmetries in the prosodic phrasing of function words: Another look at the suffixing preference. Language 90: 927-960.

Khan, Geoffrey. 2008. The Neo-Aramaic dialect of Barwar. Leiden: Brill.

Lambdin, Thomas Oden. 1982. Introduction to Sahidic Coptic. Mercer University Press.

Macaulay, Monica A. 1996. A grammar of Chalcatongo Mixtec (University of California Publications in Linguistics 127). Berkeley and Los Angeles: University of California Press.

Merrifield, William R. 1968. Palantla Chinantec grammar. Mexico: Museo Nacional de Antropología.

Merrifield, William R. \& Alfred E. Anderson. 1999. Diccionario Chinanteco de la diáspora del pueblo antiguo de San Pedro Tlatepuzco Oaxaca. Coyoacán: ILV.

Plumley, John Martin. 1948. An introductory Coptic grammar: Sahidic dialect. London: Home \& Van Thal.

Suttles, Wayne. 2004. Musqueam reference grammar. Vancouver: University of British Columbia Press.

van den Berg, René. 2013. A grammar of the Muna language. SIL e-Books 52. SIL International. (Originally published by Foris in 1989.)

Walker, Dale F. 1976. A grammar of the Lampung language: the Pesisir dialect of Way Lima. Jakarta: Universitas Katolik Indonesia Atma Jaya. 